The Bangladesh Veterinarian (2015) 32 (1) : 1 - 6

\title{
Effects of garlic extract on growth, carcass characteristics and haematological parameters in broilers
}

\author{
ZA Noman, MM Hasan, S Talukder, YA Sarker, TK Paul and MH Sikder* \\ Department of Pharmacology, Faculty of Veterinary Science, Bangladesh Agricultural \\ University, Mymensingh-2202, Bangladesh
}

\begin{abstract}
Garlic (Allium sativum) is a popular spice in Bangladesh. Its beneficial effect as growth promoter in poultry has not been studied. Broilers were grouped into four: $\mathrm{T}_{1}$ ( $1 \%$ garlic), $\mathrm{T}_{2}(2 \%$ garlic), Pc (ciprofloxacin positive control) and Nc (negative control). Aqueous extract of garlic $(1 \%$ and $2 \%)$ was administered with drinking water. $\mathrm{T}_{1}$ group $(1 \%)$ showed better performance with regard to body weight gain than $\mathrm{T}_{2}(2 \%)$, positive and negative control. In $\mathrm{T}_{1}$ group, significant difference was observed in terms of live body weight gain and dressed weight but no significant differences in feed conversion ratio, offal's weight and in blood parameters. It is suggested that $1 \%$ aqueous extraction of garlic improves growth and carcass qualities in Broilers. (Bangl. vet. 2015. Vol. 32, No. 1, 1-6)
\end{abstract}

\section{Introduction}

Feed additives are used in poultry feed to improve nutritive value and enhance performance. Antibiotics are used in broiler rations to improve productivity but have negative effects on animal and human health. Therefore, the use of antibiotic as growth promoters has not been encouraged (Castanon, 2007). Phytogenic feed additives have shown promising effects with regard to weight gain, feed efficiency, lowered mortality and increased viability in poultry (Ahmad and Khan, 2008).

Aromatic plants and essential oil extracted from them have been used as alternatives to antibiotics. For this reason, these plants are becoming more important due to their growth promoting and antimicrobial effect on animal health (Al-Kassie, 2009). Garlic (Allium satioum) is widely distributed, grown in various parts of the world and is commonly used in the food industry because of its special aroma.

Garlic has a great impact on haematological parameters, which affects the physiological, pathological and nutritional status of poultry (Oleforuh-okoleh et al., 2015). It is an important spice in traditional cooking in the Indian sub-continent, and is cheap and widely available (Huda et al., 2008). This study was designed to evaluate garlic extract as a safe growth promoting agent in broiler chickens.

\section{Materials and Methods}

\section{Study location}

Collected birds were kept at the departmental poultry shed, located at $24^{\circ} 43^{\prime} \mathrm{N}$,

*Corresponding authors:- E-mail: drmsikder@bau.edu.bd 
$90^{\circ} 25^{\prime} \mathrm{E}$, and elevation 45 feet. The study lasted for 35 days from early December 2014 to mid-January 2015.

\section{Test ingredients}

Fresh garlic was purchased from KR Shopping centre, Bangladesh Agricultural University campus. The garlic was peeled, cut into small pieces and dried at $40^{\circ} \mathrm{C}$ for 24 hours. The dried garlic was crushed by grinder (Jaipan-CM/L-7360065) and aqueous extract was prepared by Soxhlet extraction as described by Dieumou et al. (2012). One percent and $2 \%$ solutions of garlic extract were prepared.

\section{Birds' management}

A total of 40 day-old Cobb 500 broiler chicks were purchased from Nourish Poultry and Hatchery Limited, Gazipur, Bangladesh. The chicks were kept for nine days for acclimatization and were fed commercial broiler starter feed (Narish Poultry Feed Limited, Gazipur, Bangladesh) and drinking water. The brooding temperature was maintained at $35^{\circ} \mathrm{C}$ during the first week, and then lowered by $3^{\circ} \mathrm{C}$ every week until it reached room temperature $\left(25 \pm 1^{\circ} \mathrm{C}\right)$. Mean initial weight of the chicks was $35.9 \mathrm{~g}$. Newcastle disease vaccine (Baby Chick Ranikhet Disease Vaccine-BCRDV, Livestock Research Institute, Mohakhali, Dhaka, Bangladesh) was given intra-ocularly at $4^{\text {th }}$ and $21^{\text {st }}$ days.

On day 7, 40 chicks with mean body weight $91 \mathrm{~g}$ were allotted to two treatment and positive and negative control groups in a completely random design (CRD). The birds were reared in iron cages of $5 \times 4 \times 3.5$ feet. Four experimental groups were identified as $\mathrm{T}_{1}$ (1\% garlic), $\mathrm{T}_{2}$ ( $2 \%$ garlic), $\mathrm{Nc}_{\mathrm{c}}$ (negative control: only feed and water) and $\mathrm{Pc}$ [positive control: antibiotic (Ciprofloxacin, Renaflox ${ }^{\circledR}$, Renata Animal Health, Dhaka, Bangladesh, Vitamin B-complex (B-comvit ${ }^{\circledR}$, Square agrovet and pesticide, Dhaka, Bangladesh)] supplied as pharmaceuticals recommended dose.

\section{Data collection}

Birds were weighed every day. At the end of treatment blood samples were collected from the wing vein of each bird using disposable plastic syringe and needle with EDTA. After sacrifice, dressing percentages were taken and liver, heart, pancreas, gizzard and spleen were weighed.

\section{Haematological assay}

Packed Cell Volume (PCV), Total Erythrocyte Count (TEC) and Haemoglobin concentrations $(\mathrm{Hb})$ were measured as described by Lamberg and Rothstein (1977).

\section{Statistics and data analysis}

The data were analysed using general linear model procedure of Statistical Package for Social Science (SPSS) IBM 20, and comparison of means tested using Duncan's multiple range test: significance was considered at $\mathrm{P}<0.05$ (Dieumou et al., 2012). 


\section{Results and Discussion}

The effects of feeding different concentrations of garlic extract on daily body weight gain are shown in Table 1. All groups had initial body weight $91.5 \pm 1.4 \mathrm{~g}$. No birds died during the study period. Feed Conversion Ratio (FCR) is shown in Table 2, where no significant variation was evident in $\mathrm{T}_{1}$. Dressed weights of birds are shown in Table 3; better dressed weight was in $\mathrm{T}_{1}$ group $(1223.7 \pm 2.1 \mathrm{~g})$. No significance variation was found in offal weight (Table 4) and in blood profiles (Table 5).

\section{Growth performance}

In Table 1, average weight gain from day 7 to day 35 are presented at 7 day intervals. Best weight gain was experienced by $\mathrm{T}_{1}$ group at day 35 followed by $\mathrm{T}_{2}, \mathrm{Pc}_{\mathrm{c}}$ and lowest in Nc.

Table 1: Live body weight (g) of birds treated with garlic extract

\begin{tabular}{|c|c|c|c|c|c|}
\hline \multirow[t]{2}{*}{ Groups } & \multicolumn{5}{|c|}{ Body weight gain (g) } \\
\hline & Day 7 & Day 14 & Day 21 & Day 28 & Day 35 \\
\hline $\mathrm{T}_{1}$ & $89.9 \pm 0.5^{b^{*}}$ & $311.0 \pm 1.2^{\mathrm{d}}$ & $739.5 \pm 1.9^{a}$ & $1334.7 \pm 1.9 \mathrm{~b}$ & $1823.9 \pm 2.2^{a}$ \\
\hline $\mathrm{T}_{2}$ & $90.7 \pm 0.5^{b}$ & $338.5 \pm 1.2^{\mathrm{a}}$ & $732.1 \pm 1.9^{b}$ & $1113.5 \pm 1.8^{\mathrm{d}}$ & $1758.7 \pm 2.2^{\mathrm{b}}$ \\
\hline Pc & $92.5 \pm 0.5^{a}$ & $313.5 \pm 1.2^{c}$ & $709.8 \pm 1.9^{c}$ & $1352.8 \pm 1.9^{a}$ & $1755.3 \pm 2.2^{b}$ \\
\hline Nc & $92.7 \pm 0.5^{a}$ & $319.5 \pm 1.2^{\mathrm{b}}$ & $625.6 \pm 2.0^{\mathrm{d}}$ & $1129.1 \pm 3.0^{c}$ & $1527.6 \pm 2.3^{c}$ \\
\hline
\end{tabular}

*Different letters denote significant variation between groups

Supplementation with garlic extract significantly increased $(\mathrm{P}<0.05)$ body weight gain from 7 to 35 days of age, compared with the two control groups.

A number of researchers have reported growth promoting effect of garlic extract in broilers (Meraj, 1998; Javed et al., 2009; Mahmood et al., 2009; Elagib et al., 2013). It is suggested that the antibacterial compound dialkyl polysulphide present in garlic extract is playing a pivotal role in weight gain of broilers (Meraj, 1998; Ross et al., 2001).

\section{Feed Conversion Ratio (FCR)}

FCR was calculated every 7 days: the best FCR was in $T_{1}$ group at $35^{\text {th }}$ day, followed by $\mathrm{Pc}, \mathrm{T}_{2}$ and lowest was in Nc group (Table 2).

No significant $(\mathrm{P}<0.05)$ differences were recorded in FCR between treatments from 7 to 35 days of age. However, few studies showed better FCR data with garlic extract treatment (Rehman et al., 2012; Senthikumar et al., 2015).

\section{Dressed weight}

After dressing, each bird at day 35 was weighed. Among the groups $\mathrm{T}_{1}$ had highest dressed weight $(\mathrm{P}<0.05)$ followed by $\mathrm{Pc}_{1} \mathrm{~T}_{2}$ and the lowest was $\mathrm{Nc}$ group (Table 3 ). 
Table 2: Feed Conversion Ratio (FCR) of birds treated with garlic extract

\begin{tabular}{l|c|c|c|c|c}
\hline \multirow{2}{*}{ Groups } & \multicolumn{5}{|c}{ Feed Conversion Ratio (FCR) } \\
\cline { 2 - 6 } & Day 7 & Day 14 & Day 21 & Day 28 & Day 35 \\
\hline $\mathrm{T}_{1}$ & 1.2 & 1.8 & 1.6 & 1.5 & 1.6 \\
$\mathrm{~T}_{2}$ & 1.1 & 1.7 & 1.7 & 1.6 & 1.7 \\
$\mathrm{Pc}$ & 1.1 & 1.7 & 1.8 & 1.6 & 1.7 \\
$\mathrm{Nc}$ & 1.1 & 1.7 & 2.0 & 1.9 & 1.9 \\
\hline
\end{tabular}

Table 3: Dressed weight of birds treated with garlic extract

\begin{tabular}{lcc}
\hline \multicolumn{1}{c|}{ Groups } & Weight of dressed birds $(\mathrm{g})$ \\
\hline $\mathrm{T}_{1}$ & $1223.7 \pm 2.1^{\mathrm{a}}$ \\
$\mathrm{T}_{2}$ & $1076.0 \pm 2.1^{\mathrm{c}}$ \\
$\mathrm{Pc}$ & $1143.0 \pm 2.2^{\mathrm{b}}$ \\
$\mathrm{Nc}$ & $986.3 \pm 2.3^{\mathrm{d}}$ \\
\hline
\end{tabular}

*Different letters denotes significant variation among the groups

\section{Offal weight}

Individual bird's liver, gizzard, heart, spleen and pancreas were weighed: no statistically significant difference was observed $(\mathrm{P}>0.05)$.

Table 4: Offal weight of birds after dressing at day 35

\begin{tabular}{l|ccccc|}
\hline \multirow{2}{*}{ Groups } & \multicolumn{5}{|c}{ Offal's weight of birds (gm) } \\
\cline { 2 - 6 } & Liver & Gizzard & Heart & Spleen & Pancreas \\
\hline $\mathrm{T}_{1}$ & $48.1 \pm 0.5^{\mathrm{b}}$ & $27.2 \pm 0.9^{\mathrm{a}}$ & $9.3 \pm 1.9^{\mathrm{a}}$ & $2.3 \pm 0.2^{\mathrm{a}}$ & $2.3 \pm 0.2^{\mathrm{a}}$ \\
$\mathrm{T}_{2}$ & $52.5 \pm 0.5^{\mathrm{a}}$ & $21.6 \pm 0.4^{\mathrm{b}}$ & $10.0 \pm 1.9^{\mathrm{b}}$ & $3.0 \pm 0.2^{\mathrm{a}}$ & $2.5 \pm 0.2^{\mathrm{a}}$ \\
$\mathrm{Pc}$ & $52.5 \pm 0.5^{\mathrm{b}}$ & $21.0 \pm 0.4^{\mathrm{b}}$ & $10.3 \pm 1.9^{\mathrm{b}}$ & $2.5 \pm 0.2^{\mathrm{a}}$ & $2.5 \pm 0.2^{\mathrm{a}}$ \\
$\mathrm{Nc}$ & $51.6 \pm 0.5^{\mathrm{a}}$ & $19.7 \pm 0.4^{\mathrm{c}}$ & $10.3 \pm 1.9^{\mathrm{b}}$ & $2.6 \pm 0.2^{\mathrm{a}}$ & $2.6 \pm 0.2^{\mathrm{a}}$ \\
\hline
\end{tabular}

*Different letters denotes significant variation between groups

The results indicated no significant differences $(\mathrm{P}>0.05)$ between groups in weight of liver, gizzard, heart, spleen or pancreas. The lower weight of liver of birds on supplemented diets differs from Tchakounte et al. (2006) where liver and gizzard of birds on supplemented diets were well developed. Higher body weight and lower offal weight indicate good performance (Plumber and Kiepper, 2011).

It is concluded that $1 \%$ garlic extract treated group $\left(\mathrm{T}_{1}\right)$ had best performance.

\section{Haematological assay}

No significance variation was observed in blood parameters (Table 5). 
Table 5: Haematological data of birds at day 35

\begin{tabular}{l|c|c|c|c|c|c}
\hline \multirow{2}{*}{ Groups } & \multicolumn{3}{|c|}{ Mean } & \multicolumn{3}{c}{ Standard deviation } \\
\cline { 2 - 7 } & $\begin{array}{c}\text { TEC } \\
\left(\text { million } / \mathrm{cm}^{3}\right)\end{array}$ & $\begin{array}{c}\mathrm{Hb} \\
(\mathrm{g})\end{array}$ & $\begin{array}{c}\text { PCV } \\
(\%)\end{array}$ & $\begin{array}{c}\text { TEC } \\
\left(\text { million } / \mathrm{cm}^{3}\right)\end{array}$ & $\begin{array}{c}\mathrm{Hb} \\
(\mathrm{g})\end{array}$ & $\begin{array}{c}\text { PCV } \\
(\%)\end{array}$ \\
\hline $\mathrm{T}_{1}$ & 2.9 & 7.4 & 25.7 & 0.1 & 0.2 & 0.6 \\
$\mathrm{~T}_{2}$ & 2.9 & 7.6 & 28.0 & 0.1 & 0.2 & 1.0 \\
$\mathrm{PC}$ & 2.3 & 7.3 & 23.8 & 0.2 & 0.3 & 3.8 \\
$\mathrm{Nc}$ & 2.3 & 7.0 & 21.0 & 0.2 & 0.3 & 3.8 \\
\hline
\end{tabular}

There was no significant increase $(\mathrm{P}>0.05)$ in the $\mathrm{PCV}, \mathrm{Hb}$ and TEC of birds in treated groups compared with control. High PCV, Hb, and RBC indicate improved oxygencarrying capacity of the cells, which translate to better availability of nutrients (Oleforuh-Okoleh et al., 2015). Garlic extract (1\%) shows highest mean TEC, $\mathrm{Hb}$ and PCV (2.9, 7.4 and 25.7) and lowest standard deviation (0.1, 0.2 and 0.6). Administration of garlic extract reduced the platelets in the blood. Lawson et al. (1992) reported that garlic could decrease the sensitivity of platelets as aggregating agents. This implies that garlic extract could improve blood circulation on account of its inhibitory effects on platelet aggregation.

\section{Conclusions}

Aqueous extract of garlic showed better performance than positive and negative control groups. Among garlic extracts, $1 \%$ garlic extract showed better performance in relation to carcass weight than $2 \%$. It is suggested that garlic extract can be used as an alternative organic growth promoter in poultry.

\section{References}

Ahmad T, Khan S 2008: Evaluation of different medicinal plants as growth promoters for broiler chicks. Sarhad Journal of Agriculture 24 323-330.

Al-Kassie GAM 2009: Influence of two plant extracts derived from thyme and cinnamon on broiler performance. Pakistan Veterinary Journal 29 169-173.

Castanon JIR 2007: History of the use of antibiotic as growth promoters. Journal of Poultry Science 86 2466-2471.

Dieumou FE, Teguia A, Kuiate JR, Tamokou JD, Doma UD, Abdullahi US, Chiroma AE 2012: Effect of diets fortified with garlic organic extract and streptomycin sulphate on growth performance and carcass characteristics of broilers. International Journal of Livestock Production 3 36-42.

Elagib HAA, El-Amin WIA, Elamin KM, Malik HEE 2013: Effect of dietary garlic (Allium sativum) supplementation as feed additive on broiler performance and blood profile. Journal of Animal Science Advances 3 58-64. 
Huda FA., Islam MS, HB, Islam MS 2008: Impact assessment study on selected spice crops under action plan in Bangladesh. Progressive Agriculture 19 229-241.

Javed M, Durrani F, Hafeez A, Khan RU, Ahmad I 2009: Effect of aqueous extract of plant mixture on carcass quality of broiler chicks. ARPN Journal of Agricultural and Biological Science 4 37-40.

Lamberg SL, Rothstein R 1977: Laboratory Manual of Hematology and Urinalysis, West Port Connecticut, USA: Avi. Publishing Company, Inc.

Lawson LD, Ransom DK, Hughes BG 1992: Inhibition of whole blood platelet-aggregation by compounds in garlic clove extracts and commercial garlic products. Thrombosis Research 65 141-156.

Mahmood S, Hassan MM, Alam M Ahmad F 2009: Comparative efficacy of Nigella sativa and Allium satioum as growth promoters in broilers. International Journal of Agricultural and Biological Science 11 775-778.

Meraj ICA 1998: Effect of garlic and neem leaves supplementation on the performance of broiler chickens. MSc Thesis, Department of Poultry Science, University of Agriculture, Faisalabad, Pakistan.

Oleforuh-Okoleh VU, Ndofor-Foleng HM, Olorunleke SO, Uguru JO 2015: Evaluation of growth performance, haematological and serum biochemical response of broiler chickens to aqueous extract of ginger and garlic. Journal of Agricultural Science 7 167-174.

Plumber HS, Kiepper BH 2011: Impact of poultry processing by-products on wastewater generation, treatment and discharges. In Proceedings of the 2011 Georgia Water Resources Conference, University of Georgia, 11-13 April, USA.

Rehman ZU, Khan S, Chand N, Tanweer AJ, Sultan A, Akhtar A, Tauqeer AM 2012: Effect of water based mixture infusion of Allium sativum and Withania somnifera on performance of broiler chicks. Pakistan Journal of Science 64 180-183.

Ross ZM, O'Gara EA, Hill DJ, Sleightholme HV, Maslin DJ 2001: Antimicrobial properties of garlic oil against human enteric bacteria: evaluation of methodologies and comparisons with garlic oil sulfides and garlic powder. Applied Environmental Microbiology 67 475-480.

Senthilkumar S, Madesh N, Purushothaman MR, Vasanthakumar P, Thirumalaisamy G, Sasikumar P 2015: Effect of garlic supplementation on performance in broilers - a Review. International Journal of Science, Environment and Technology 4 980-983.

Tchakounte J, Bopelet M, Ngoungoupayou JD, Dongmo T, Meffeja F, Fotso J 2006: Influence de la consommation de la boue d'huile de palme sur les performances zootechniques et économiques des poulets de chair en phase de finition. Livestock Research for Rural Development 18173. 